\title{
III. THE DIVERSE EFFECTS OF NORMAL HUMAN SERUM*
}

\author{
BY
}

\author{
J. F. MCCALL AND J. R. E. FRASER \\ From the University of Melbourne Department of Medicine, The Royal Melbourne Hospital, Victoria, Australia
}

In the course of an earlier study, we found that cytoplasmic spreading of human synovial cells was strongly inhibited by a high titre of human serum in the native state, in contrast with the effect of heatinactivated serum (Fraser and McCall, 1966). We used a titre higher than is usual in tissue culture, but we had previously found that a comparable level of heat-inactivated serum was well tolerated by synovial cells. The inhibition we observed in normal serum was unexpected.

Other studies of the effects of normal human serum have used a variety of titres, cells, and experimental methods, with a corresponding variety of results which are discussed below. The following experiments were undertaken to confirm and extend our earlier findings, and so to facilitate other projected experiments. It will be shown that human serum exerts three distinct effects upon cytoplasmic spreading of homologous cells.

\section{Methods}

Human synovial cells were isolated and grown by serial passage, as previously described (Fraser and McCall, 1965). Diploid human skin cells of connective-tissue type $\dagger$ had been re-established in culture

* This study was made possible by grants from the Arthritis and Rheumatism Research Council for Great Britain and the Commonwealth, the National Health and Medical Research Council of Australia, and the Australian Rheumatism Council.

+ Kindly provided by Miss Jean Ferguson, M.Sc., Commonwealth Serum Laboratories. from deep-freeze storage after eight passages. Stock cultures of synovial cells were maintained in Mediun 199 supplemented with 10 per cent. foetal calf serum and 5 per cent. human serum. Skin cells were maintaineđึ in medium 199 with 20 per cent. foetal calf serum.

Serum was prepared from normal subjects fasted. overnight. After clot retraction, blood was centrifugeđ at $4^{\circ} \mathrm{C}$., and aliquots of serum were put into rubberg capped vials. One aliquot was heated for 30 minutes af $56^{\circ} \mathrm{C}$. or other specified temperature, while the rest werê kept chilled. All samples were brought to $37^{\circ} \mathrm{C}$. befores use. The experiment was usually established within 4 hours of venesection by the method as described beforw (McCall and Fraser, 1966).

Most of the experiments were designed to study spread $=$ ing of synovial or skin cells in individual sera in concene trations of 10 and 50 per cent., both in the native state and heat-inactivated. Three experiments compare $\bar{\Phi}$ spreading in aliquots of serum previously treated a several temperatures.

Until the experiments with synovial cells were confos pleted, no other cell strains were kept in the laborator

\section{Results}

Human Serum and Human Synovial Cells.-The findings are recorded in Table I (opposite) and Fig. $1 \overrightarrow{0}$

In the higher titre, native serum again consistently inhibited cell spreading in contrast with heat
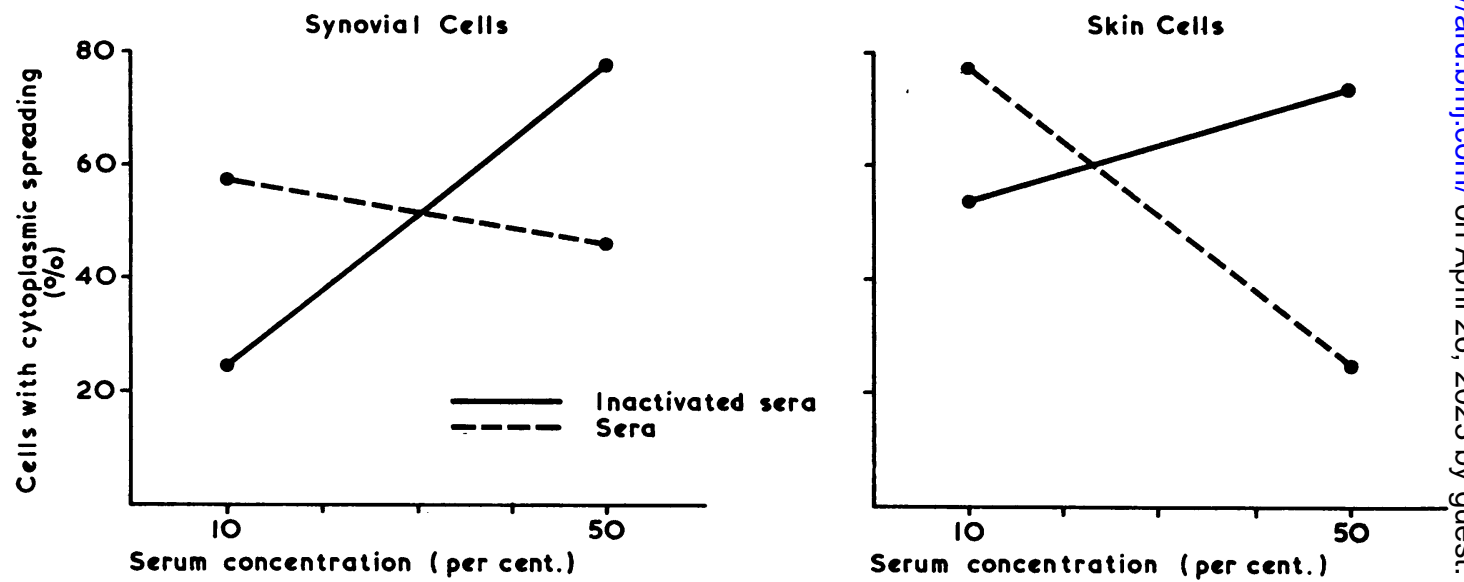

Fig. 1.-Spreading of synovial and skin cells in native and heat inactivated human serum after 48 hours. 
TABLE I

EFFECTS OF NATIVE (N) AND HEAT-INACTIVATED (H) NORMAL SERUM ON SYNOVIAL CELLS

\begin{tabular}{|c|c|c|c|c|c|c|c|c|c|c|c|}
\hline \multirow{4}{*}{$\begin{array}{c}\text { Subject } \\
\text { No. }\end{array}$} & \multicolumn{2}{|c|}{ Blood Groups } & \multirow{4}{*}{$\begin{array}{l}\text { Age of } \\
\text { Culture } \\
\text { (days) }\end{array}$} & \multicolumn{8}{|c|}{ Percentage of Cells with Cytoplasmic Spreading } \\
\hline & \multirow{3}{*}{$\begin{array}{l}\text { Serum } \\
\text { Donor }\end{array}$} & \multirow{3}{*}{$\begin{array}{r}\text { Cell } \\
\text { Donor }\end{array}$} & & \multicolumn{4}{|c|}{24 hours } & \multicolumn{4}{|c|}{48 hours } \\
\hline & & & & \multicolumn{2}{|c|}{50 per cent. } & \multicolumn{2}{|c|}{10 per cent. } & \multicolumn{2}{|c|}{50 per cent. } & \multicolumn{2}{|c|}{10 per cent. } \\
\hline & & & & $\mathbf{H}$ & $\mathbf{N}$ & $\mathbf{H}$ & $\mathbf{N}$ & $\mathbf{H}$ & $\mathbf{N}$ & $\mathbf{H}$ & $\mathbf{N}$ \\
\hline 1 & $\mathbf{O}$ & $\mathbf{A}$ & 21 & 87 & 41 & 80 & 82 & 96 & 57 & 84 & 87 \\
\hline 2 & B & A & 21 & 78 & 32 & 34 & 25 & 82 & 54 & 18 & 12 \\
\hline 3 & $\mathbf{O}$ & $\mathbf{O}$ & 48 & 36 & 25 & 5 & 49 & 37 & 40 & 12 & 53 \\
\hline 4 & $\mathbf{A}$ & 0 & 49 & 49 & 28 & 22 & 44 & 73 & 59 & 11 & 48 \\
\hline 5 & 0 & 0 & 56 & 25 & 13 & 13 & 43 & 65 & 19 & 15 & 52 \\
\hline 6 & 0 & 0 & 61 & 55 & 20 & 8 & 36 & 78 & 45 & 8 & 51 \\
\hline 7 & B & A & 41 & 66 & 66 & 69 & 88 & 90 & 77 & 45 & 89 \\
\hline 8 & 0 & 0 & 63 & 39 & 25 & 9 & 57 & 86 & 38 & 17 & 83 \\
\hline 9 & $\mathbf{A}$ & 0 & 70 & 87 & 19 & 44 & 34 & 91 & 34 & 35 & 36 \\
\hline 10 & 0 & 0 & 76 & 21 & 11 & 5 & 21 & 67 & 30 & 3 & 63 \\
\hline Means & & & & $54 \cdot 3$ & $28 \cdot 0$ & $28 \cdot 9$ & $47 \cdot 9$ & $76 \cdot 5$ & $45 \cdot 3$ & $24 \cdot 8$ & $57 \cdot 4$ \\
\hline
\end{tabular}

INTERACTION TABLES, TOTALS OF TRANSFORMED VALUES*

\begin{tabular}{|c|c|c|c|}
\hline \multirow{2}{*}{ Time (hrs) } & \multicolumn{2}{|c|}{ Serum Concentration (per cent.) } & \multirow{2}{*}{ Total } \\
\hline & 50 & 10 & \\
\hline $\begin{array}{l}24 \\
48\end{array}$ & $\begin{array}{r}793 a \\
1044 a\end{array}$ & $\begin{array}{c}732 a \\
780 a\end{array}$ & $\begin{array}{l}1525 b \\
1824 b\end{array}$ \\
\hline Total & $1837 b$ & $1512 b$ & 3349 \\
\hline
\end{tabular}

\begin{tabular}{|c|c|c|c|}
\hline \multirow{2}{*}{$\begin{array}{l}\text { State of } \\
\text { Serum }\end{array}$} & \multicolumn{2}{|c|}{ Serum Concentration (per cent.) } & \multirow{2}{*}{ Total } \\
\hline & 50 & 10 & \\
\hline $\begin{array}{l}\text { Heat-Inactivated } \\
\text { Native }\end{array}$ & $\begin{array}{r}1102 a \\
735 a\end{array}$ & $\begin{array}{l}589 a \\
923 b\end{array}$ & $\begin{array}{l}1691 b \\
1658 b\end{array}$ \\
\hline Total & $1837 b$ & $1512 b$ & 3349 \\
\hline
\end{tabular}

Standard Errors: Treatment Totals a (of 20) $=42$ Marginal Totals $b$ (of 40) $=59$

To compare two treatment totals, significant differences at 5 per cent. level $=116$, and at

1 per cent. level $=153$
* Derived from analysis of variance after angular transformation (Fisher and Yates, 1953). Note: The residual error was identical in both synovial and skin cell series. inactivated serum. In the lower titre, the reverse was true; spreading was distinctly greater in seven of the ten specimens of native serum. The difference

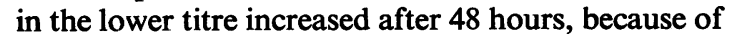
regression of spreading in heat-activated serum. This striking inversion of the effect of native serum by ailution is shown graphically in Fig. 1, and con- trasts with the effect of heat-inactivated serum which shows a simple positive relationship to concentration. In this series of experiments, the last-mentioned effect dominates the aggregate effect of concentration as shown in the interaction table.

With passage of time there was a highly significant increase in spreading, chiefly in the higher titre. 
Human Serum and Human Skin Cells.-Eight of the ten sera were from the same donors as those used in the study of synovial cells. The same phenomena were observed with individual sera (Table II), although the aggregate effects of the several preparations of skin cells differed from those observed with synovial cells. Thus the composite effect of serum concentration revealed a significantly greater degree of spreading in the lower titre. In comparison with synovial cells, spreading of skin cells in heatinactivated serum was a little less in 50 per cent. but much better in 10 per cent. concentration. However, the inhibition by native serum in the high titre was so great that the apparent inversion of the effect oæ native serum was even more pronounced than in th $\bar{P}$ experiments with synovial cells (cf. Fig. 1).

Morphological Changes. - Skin and synovial cells appeared similar in these experiments. In the. earliest stages, skin cells showed more tendency t $\vec{\xi}$ spread in an annular rather than a polar fashion? Thereafter individual cells of each type were indistine guishable. Fig. 2 ( $a$ to $d$ ) (opposite) shows skin cell allowed to grow another 24 hours after the end of a experiment. Cell multiplication has accentuated the selective effects of serum upon attachment anक्ष spreading. Fine debris is apparent in $(b),(c)$ and

TABLE II

EFFECTS OF NATIVE (N) AND HEAT-INACTIVATED (H) NORMAL SERUM ON SKIN CELLS*

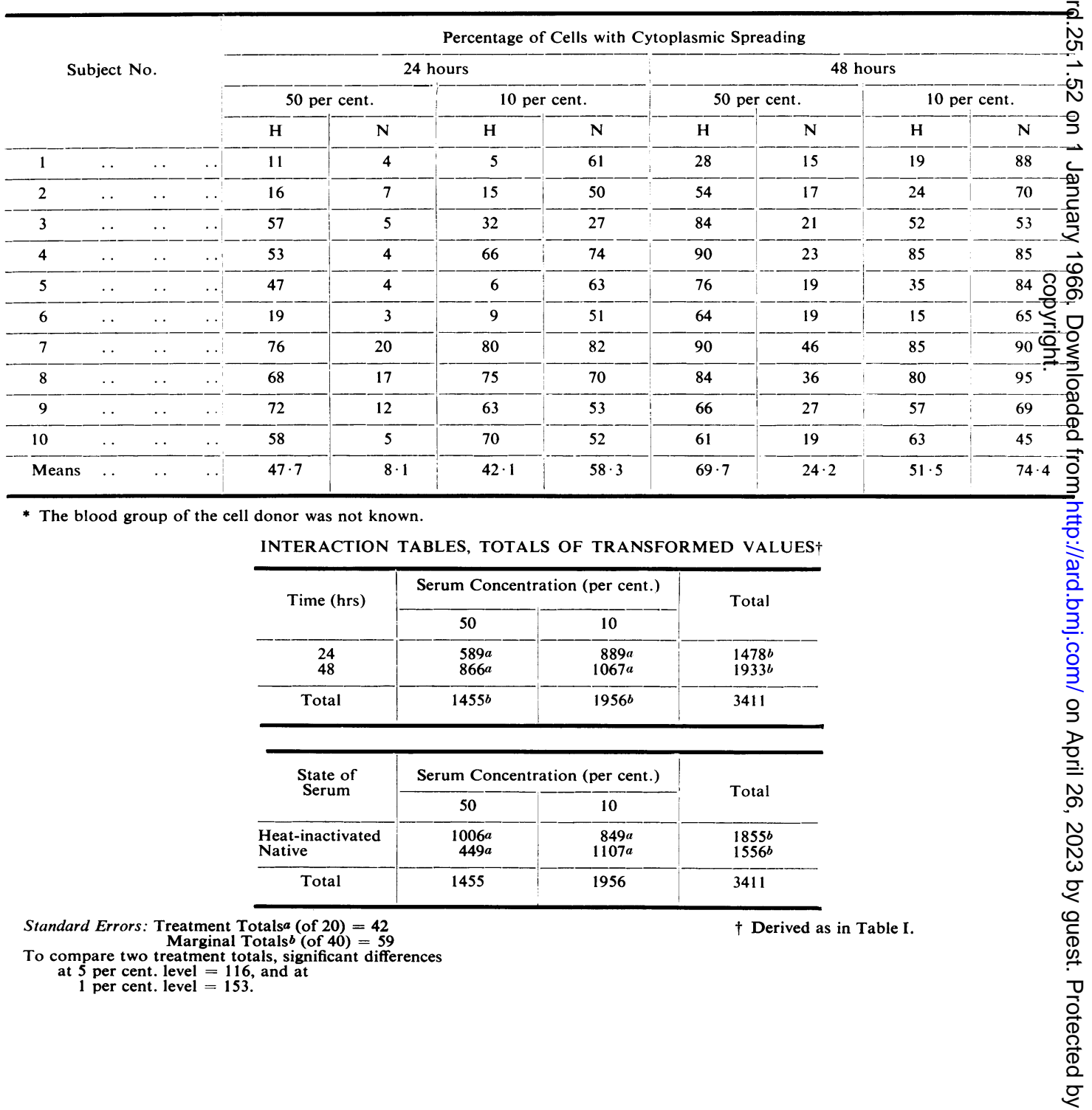



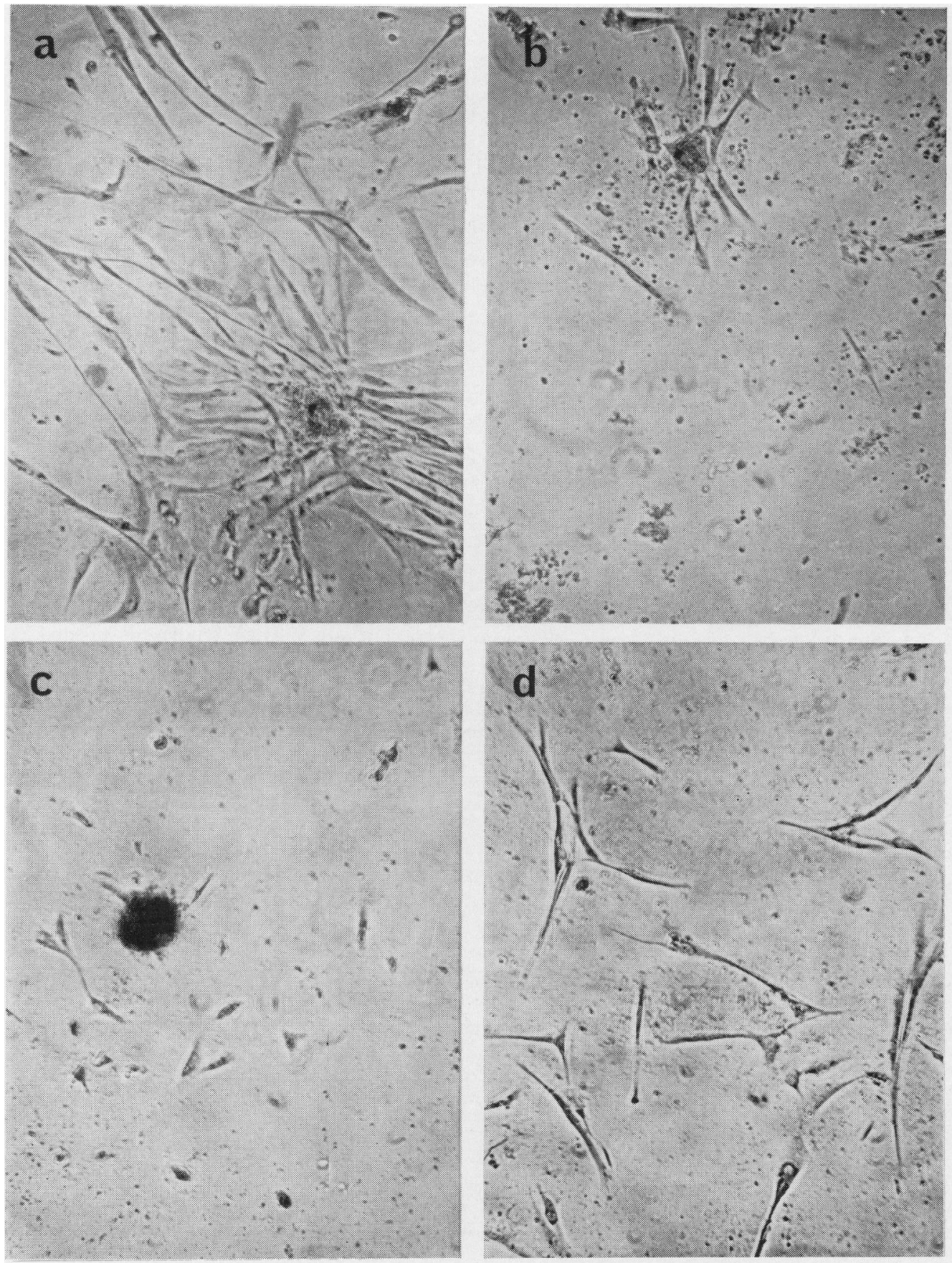

Fig. 2.-Skin cells. Replicate cultures after $72 \mathrm{hrs}$ in (a) 50 per cent. serum, heat-inactivated, (b) 50 per cent. serum, native state, $(c) 10$ per cent. serum, heat-inactivated $(d) 10$ per cent. serum, native state. 
(d). Dissolution of rounded cells is seen in $(b)$ and clumping in $(c)$. Proportionate counts of spread cells would no longer be possible.

Graded Heat-inactivation of Serum.-Synovial cells were studied in 50 per cent. concentration of serum in the native state and after heating for 30 minutes at 45,52 , and $56^{\circ} \mathrm{C}$ (Table III). Spreading after 24 hours showed a significant difference between the effects of native serum and that heated to $52^{\circ} \mathrm{C}$., and between the specimens heated to 45 and $56^{\circ} \mathrm{C}$. Thus the inhibitory effect of serum was reduced in direct proportion to the degree of heatinactivation. Progressive spreading after 48 hours narrowed the difference between the several treatments.

\section{Discussion}

Human serum exhibits three separate effects on the cytoplasmic spreading of human synovial and skin cells in culture.

(1) There is heat-stable spreading activity, which in low titre has relatively less effect on synovial cells.

(2) There is invariably a heat-labile inhibition of spreading of both cell strains by high titre.

(3) A heat-labile activation of spreading is usually apparent in low titre.
Both skin and synovial cells revealed the same three properties of serum, although the two types of cell reacted in different degrees. The betten spreading of skin cells in low titres might have. resulted from the higher concentration of foetal calf? serum used in their stock cultures, but this would no $\vec{E}$ explain their greater sensitivity to the high titre of native serum. Whether or not these distinctions: are inherent in each strain, it is pertinent that the behaviour of the cells should distinguish them more clearly than their appearance.

Many studies have described inhibition or injuryen of cell cultures by native human serum, but mos $\overrightarrow{0}$ have concerned heterologous cells. For example $\overrightarrow{2}$ Fedoroff (1956) found that human serum, especiallyw from schizophrenic patients, often caused muchw damage to L cells, of murine origin, but not to the human strain HeLa. He applied this observation later (Fedoroff, 1962) to separate human and murinecells in mixed culture. Kunin, Emmons, an \& Jordan (1960) also used human serum selectively tog eliminate a subprimate cell contaminant from Chang human liver cells. Bolande (1960) and Bolande and McClain (1960) found that human serum exerted heat-labile cytotoxic effect upon transformed humare and heterologous cells but not upon normal human or rabbit cells. Their studies of normal cells inso

TABLE III

EFFECT OF HEAT-INACTIVATION OF SERUM* ON SYNOVIAL CELL SPREADING

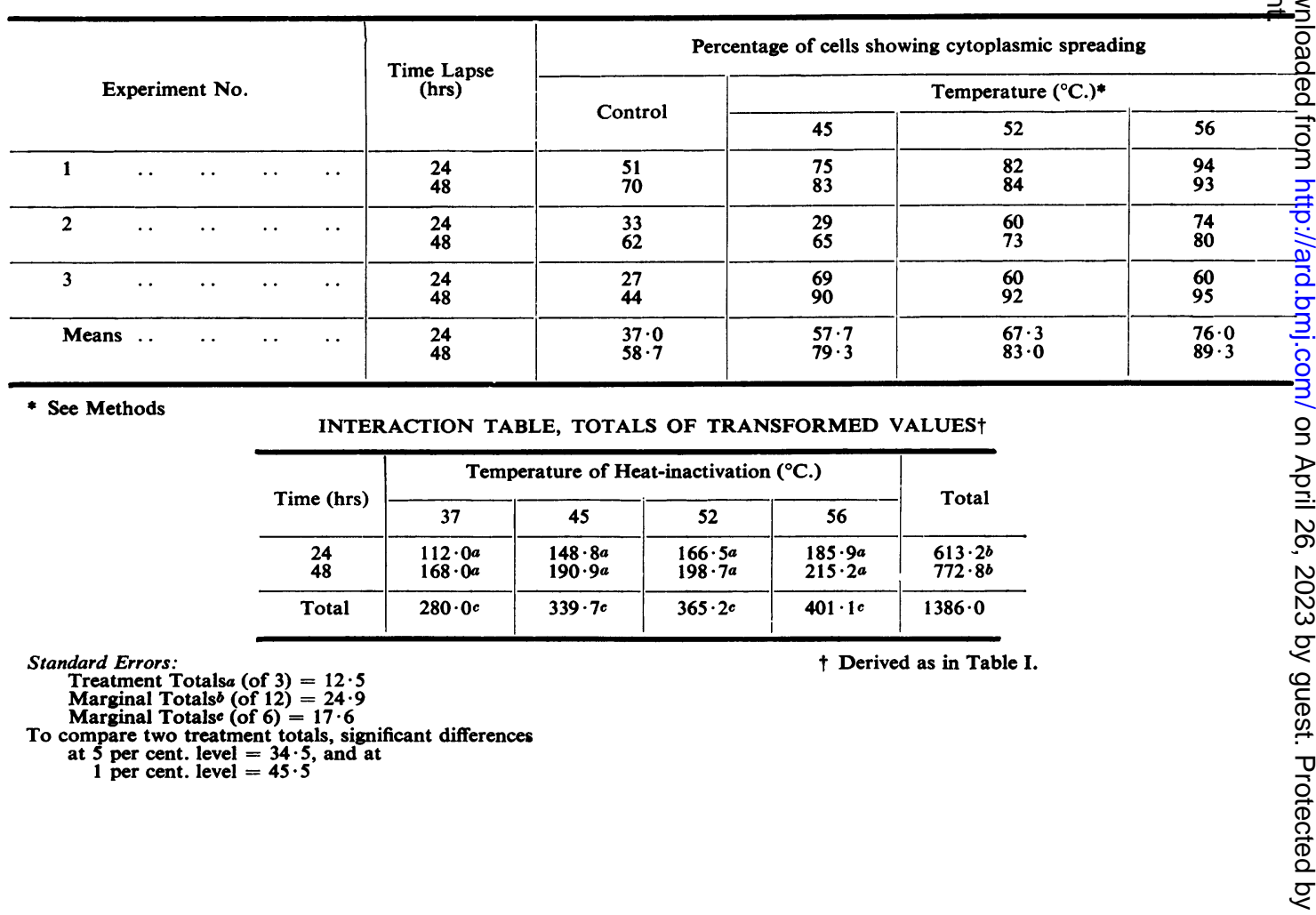


volved the exposure of established cultures to serum for 1 hour only. They concluded that human serum contains naturally-occurring cytotoxins whose function is to destroy cells genetically alien to the host. However, it is a moot point whether this facility is inherent or acquired as Fedoroff and Webb (1962) found that human serum cytotoxins for mouse cells reacted also with common enteric bacteria. Thus the cytotoxins might readily be acquired.

The above-mentioned studies have, by and large, failed to demonstrate much cytotoxic action of human serum upon homologous cells. However, there are several possible reasons for such failure. As we have found in our own work, the sensitivity of different cell strains may not be the same. The preparation of serum may easily reduce the labile cytotoxic activity. Fedoroff (1956) and Bolande (1960) both used a high titre, but first stored the blood at $4^{\circ} \mathrm{C}$. for 24 hours or more. The state of the cells would seem an equally important determinant of the outcome.

The use of trypsinized cells in suspension and their immediate exposure to high titres of fresh serum appear the most likely reasons for our finding such a consistent inhibitory effect. Penttinen and Saxén (1959) have used a similar technique in which human cells, transformed or recently isolated, were directly established in fresh human serum. They found that some sera caused strong clumping of cells and a drop in numbers. This action was impaired rapidly by heating at $52^{\circ} \mathrm{C}$., gradually by storage at $4^{\circ} \mathrm{C}$., was removed by previous absorption with zymosan, and was stable in deep-freeze storage. The effect was shown in mild degree by some sera and not at all by others. Serum was used in a concentration of 30 per cent. in these and their later experiments (Saksela, Saxén, and Penttinen, 1960). Examination of Fig. 1 suggests that we should have found a similar variable response to native serum in this titre. Our observations of the effects of native serum in 10 per cent. concentration confirm those of Weiss (1959), who found that cell attachment in this titre was better in native than in heat-inactivated human serum.

Thus each of the several properties we have demonstrated simultaneously in human serum has been shown in other studies using single titres. We have not yet identified these effects with specific fractions of serum and until evidence is obtained, it would be inadvisable to assume that each is due to a separate substance. It is common observation that a single agent-for example, heat-may stimulate or injure living tissues, depending on the intensity of the application. There are analogies closer to the present observations. For example, the damaging effect of tuberculin on sensitized cells is inverted by dilution (Waksman and Matoltsy, 1958). It has also been found that the inhibitory effect of human serum upon glycolysis of heterologous cells is converted to one of enhancement by dilution or by heatinactivation (Landy, Michael, Trapani, Achinstein, Woods, and Shear, 1960). Thus the reactions of human serum with homologous and heterologous cells are remarkably similar in kind, if not in degree. Whether the underlying mechanisms are similar remains to be seen.

\section{Summary}

The cytoplasmic spreading of human synovial and skin cells cultured in vitro was studied in the presence of normal human serum, native and heat-inactivated, in high and low titres.

Three effects of serum were defined:

(a) A heat-stable activation of spreading, proportional to the titre;

(b) A potent heat-labile inhibition manifest in all sera studied;

(c) A heat-labile activation of spreading revealed in most sera by dilution to a low titre.

Certain quantitative differences were revealed in the behaviour of synovial and skin cells.

The implication of these findings is discussed.

We are indebted to Prof. E. J. Williams and Miss B. Laby for statistical analysis; to Prof. R. R. H. Lovell and Miss J. Ferguson for advice and criticism; and to Miss B. Nadudvary for technical assistance.

\section{REFERENCES}

Bolande, R. P. (1960). Lab. Invest., 9, 475. and McClain, J. P. (1960). Proc. Soc. exp. Biol. $(N . Y), 103,345$.

Fedoroff, S. (1956). J. Lab. clin. Med., 48, 55.

- (1962). Nature (Lond.), 196, 394. and Webb, S. J. (1962). Ibid., 193, 80

Fisher, R. A., and Yates, F. (1953). "Statistical Tables for Biological, Agricultural, and Medical Research", 4th ed. Oliver and Boyd, Edinburgh.

Fraser, J. R. E., and McCall, J. F. (1965). Ann. rheum. Dis., 24, 351.

- (1966). Ibid., 25, 49.

Kunin, C. M., Emmons, L. R., and Jordan, W. S., Jr. (1960). J. Immunol., 85, 203.

Landy, M., Michael, J. G., Trapani, R. J., Achinstein, B., Woods, M. W., and Shear M. J. (1960). Cancer Res., 20, 1279.

McCall, J. F., and Fraser, J. R. E. (1966). Ann. rheum. Dis., 25, 42.

Penttinen, K., and Saxén, E. (1959). Nature (Lond.), 184,1570 . 
Saksela, E., Saxén, E., and Penttinen, K. (1960). Exp. Cell Res., 19, 402.

Waksman, B. H., and Matoltsy, M. (1958). J. Immunol., 81, 220.

Weiss, L. (1959). Exp. Cell Res., 17, 499.

III. Les divers effets du sérum humain normal.

\section{RÉSUMÉ}

On étudia l'expansion cytoplasmique des cellules synoviales et cutanées in vitro en présence du sérum humain normal, naturel et inactivé par la chaleur, aux taux bas et élevés.

On définit trois effets du sérum:

(a) l'activation de l'expansion thermostable, proportionnelle au titre;

(b) l'inhibition thermolabile puissante, manifeste dans tous les sérums étudiés;

(c) l'activation thermolabile de l'expansion démontrée dans la plupart des sérums par la dilution à un bas titre.
On trouva de certaines différences quantitatives dans? le comportement des cellules synoviales et cutanées. On discute la portée de ces résultats.

\section{Varios efectos del suero humano normal}

\section{Sumario}

Se estudió la expansión citoplásmica de las célulaș sinoviales y cutáneas in vitro en la presencia del sueroo humano normal, natural e inactivado por el calor, en concentraciones altas y bajas.

Tres efectos del suero fueron definidos:

(a) la activación de la expansión termostable, propor-n cional a la concentración;

(b) la inhibición termolabíl poderosa, presente en $\overrightarrow{0}$ todos los sueros estudiados;

(c) la activación termolabíl de la expansión demo $\overrightarrow{\vec{\omega}}$ strada en la mayoría de los sueros a bajar lap concentración.

Se hallaron ciertas diferencias cuantitativas en e⿳亠丷厂 comportamiento de las células sinoviales y cutáneas.

Se discuten las implicaciones de estos resultados. 